\title{
Greetings from Sri Lanka
}

Journal of the Ceylon College of Physicians, 2016, 47, 107

DOI: http://doi.org/10.4038/jccp.v47i2.7795

\section{Sarath Gamini De Silva ${ }^{1}$}

Working thousands of miles apart
Yet practising the same noble art
To relieve suffering playing our part
Keeping updated we have been smart

Over the years we have managed to meet

In your cooler climes or Colombo's heat

For intellectual pursuit, has been a treat

In productive harmony our hearts beat

For many years we have been close

For mutual benefit whenever we chose

Grasping opportunities as they arose

Fruitful interaction, having a good dose

Doing the very best for our membership

While promoting everlasting friendship

Granting opportunities for scholarship

I thank you for the honorary fellowship

We have interests so wide and diverse

To academic stagnation we are averse

Whatever we gained let us not reverse

Greetings from Sri Lanka

I bring in verse 